\title{
Volatile extraction from soybean plants infested with several herbivores
}

\section{Extração de voláteis de plantas de soja infestadas por múltiplos herbívoros}

\author{
Dalila Dominique Duarte ROCHA ${ }^{1}$; Marcos Antônio Matiello FADINI ${ }^{2}$ \\ Otávio Augusto Carvalho de SOUZA ${ }^{3}$; Rodinei AUGUSTI4; Julio Onesio Ferreira MELO ${ }^{5}$
}

${ }^{1}$ Mestre em Ciências Agrárias, Universidade Federal de São João Del Rei, Campus Sete Lagoas, Sete Lagoas, MG, Brasil

2 Professor Associado, Universidade Federal de São João Del Rei, Campus Sete Lagoas, Sete Lagoas, MG, Brazil

${ }^{3}$ Graduando em Engenharia de Alimentos, Universidade Federal de São João Del Rei, Campus Sete Lagoas, Sete Lagoas, MG, Brasil

${ }^{4}$ Professor Titular, Universidade Federal de Minas Gerais, Departamento de Química, Belo Horizonte, MG, Brasil

${ }^{5}$ Autor para correspondência. Professor Associado, Universidade Federal de São João Del Rei, Campus Sete Lagoas, Sete Lagoas, MG, Brasil; e-mail:onesiomelo@gmail.com

Recebido em: 18-12-2018; Aceito em: 14-06-2019

\begin{abstract}
The oral secretion of herbivores triggers chemical defenses in plants. When subjected to simultaneous or sequential attack by herbivores, plants emit volatile compounds of varying chemical nature, which can interfere with the attraction of natural enemies. This study investigates the profile of volatile compounds emitted by transgenic soybean (Bt M6210 IPRO) plants infested with Tetranychus urticae Koch (Acari: Tetranychidae) and Anticarsia gemmatalis Hübner (Lepidoptera: Noctuidae). To this end, we used a method without leaf maceration. For plant infestation, $100 \mathrm{~T}$. urticae mites per plant were used for one day and, subsequently, 2 A. gemmatalis caterpillars for 36 hours. Volatile compounds produced after infestation were analyzed by gas chromatography coupled with mass spectrometry. Principal component analysis showed differences between groups of compounds and explained $77.5 \%$ of the variation in volatiles. There are chemical differences between the emission of compounds according to the type of herbivory. It is concluded that soybean plants infested in a single ( $T$. urticae) or multiple ( $T$. urticae followed by $A$. gemmatalis) way trigger the production of volatile compounds that can be used as chemical traces to direct the foraging of natural enemies. The possible functions of volatiles produced after herbivory are discussed.
\end{abstract}

Additional keywords: Anticarsia gemmatalis; gas chromatography coupled with mass spectrometry; multiple attack; solid-phase microextraction; Tetranychus urticae.

\begin{abstract}
Resumo
A secreção oral dos herbívoros aciona rotas químicas de defesas nas plantas. Ao serem submetidas ao ataque simultâneo ou sequencial de herbívoros, as plantas emitem compostos voláteis de variada natureza química que podem interferir na atração de inimigos naturais. Objetivou-se investigar o perfil dos compostos voláteis emitidos por plantas de soja transgênica (Bt) M6210IPRO infestadas com Tetranychus urticae Koch (Acari: Tetranychidae) e Anticarsia gemmatalis Hübner (Lepidoptera: Noctuidae) utilizando metodologia que não implicasse na maceração das folhas. Para infestação das plantas, foram utilizados 100 ácaros de $T$. urticae por planta durante um dia e, em sequência, 2 lagartas de $A$. gemmatalis durante 36 horas. Os compostos voláteis produzidos após infestação foram analisados por cromatografia gasosa acoplada à espectrometria de massas. A análise de componentes principais mostrou diferenças entre os grupos de compostos e explicou $77,5 \%$ da variação dos voláteis. Observou-se que existem diferenças químicas entre a emissão de compostos segundo o tipo de herbivoria. Conclui-se que plantas de soja infestadas por $T$. urticae, de maneira simples e múltipla ( $T$. urticae seguido por $A$. gemmatalis), acionam a produção de compostos voláteis que podem ser utilizados como pistas químicas para direcionar o forrageamento de inimigos naturais. As possíveis funções dos voláteis produzidos após herbivoria são discutidas.
\end{abstract}

Palavras-chave adicionais: Anticarsia gemmatalis; cromatografia gasosa acoplada à espectrometria de massas; micro-extração em fase sólida; múltiplo ataque; Tetranychus urticae.

\section{Introduction}

Plants have constitutive defenses against herbivores, which are characterized by the continued presence of morphological structures or chemicals that can negatively affect biological parameters related to herbivore development and reproduction (Coley \& Barone, 1996). These structures and substances can be found in plants depending on the phenological stage (Coley \& Barone, 1996).

Plants can also respond to herbivory by triggering metabolic pathways for defense induction 
(Dicke et al., 2009). Indirect induced defense is characterized by the emission of volatile organic compounds (VOCs) that attract natural enemies (Poecke \& Dicke, 2004; Leitner et al., 2005; Aartsma et al., 2017). The chemical nature of these compounds differs as a function of the herbivore feeding mode (Dicke et al., 2009). Chewers commonly trigger the jasmonic acid (JA) route, while suckers trigger the salicylic acid (SA) route (Leitner et al., 2005; Yoneya \& Takabayashi, 2014; Aartsma et al., 2017). Jasmonic acid is synthesized through the octadecanoid pathway after the release of linolenic acid from biomembranes (Heil, 2014).

Soybean crops are the target of attacks by multiple herbivore pests such as caterpillars and mites (Guedes et al., 2007; Roggia et al., 2008; Moscardi et al., 2012; Rezende et al., 2014). Most research on volatile compounds that are triggered in indirect induced defense in soybeans traditionally use methods such as SPME (solid-phase microextraction) (Gomes et al., 2017). In this kind of method, it is previously necessary to remove and macerate plant tissues, and the analysis focuses on the effects of interactions between the plant and only one insect species (Moraes et al., 2005; Michereff et al., 2011; Cai et al., 2015). However, such techniques address a local response to plant emissions, and the challenges lie in the search for methods that assess the systemic response of the plant, particularly after being subjected to attack by more than one herbivore (Zhang et al., 2009).

Arid-brindle Tetranychus urticae Koch (Acari: Tetranychidae) is a generalist, considered a primary pest in many crops (Razmjou et al., 2009). It has been reported to attack soybeans in several Brazilian regions (Guedes et al., 2007; Rezende et al., 2014), causing severe damage. Soybean caterpillar Anticarsia gemmatalis Hübner, 1818 (Lepidoptera: Noctuidae) is considered important in the crop, with reports of its occurrence in all Brazilian growing regions (Moscardi et al., 2012). Several studies show that besides insects, there are several species of pest mites attacking soybean crops during the vegetative stage (Roggia, 2008).

Studying volatiles without causing physical damage to plants (i.e., removal of their leaves and tissues) is critical to understanding plant defenses and to simulate more likely field conditions (Dicke et al., 2009; Ponzio et al., 2016; Aartsma et al., 2017; Giron et al., 2018). Therefore, we investigated the emission of volatile compounds using a noninvasive technique in soybean plants under multiple herbivory by $T$. urticae and $A$. gemmatalis.

\section{Materials and methods}

\section{Breeding of Tetranychus urticae and Anticarsia gemmatalis}

Jack bean (Canavalia ensiformis) seeds were sown in plastic pots $(6.3 \mathrm{~L}$ ) containing substrate (Terral Solo ${ }^{\circledR}$, which were kept in cages with anti-aphid screen in a greenhouse $\left(25 \pm 5^{\circ} \mathrm{C}\right)$ for establishment of $T$. urticae.
A. gemmatalis caterpillars were bred by the team of the Biological Control Laboratory of Embrapa Maize and Sorghum, in Sete Lagoas city, Minas Gerais State. These caterpillars fed on artificial diet (Vilela et al., 2014) and sugary solution (50\%) during the adult phase. Adult moths were placed in cylindrical PVC cages (30 cm in diameter and $20 \mathrm{~cm}$ in height) for copulation and oviposition. Napkins containing eggs were removed from the cages and stored in plastic bags at a controlled temperature $\left(25 \pm 2{ }^{\circ} \mathrm{C}\right)$. After hatching, the larvae were individualized in $50-\mathrm{mL}$ lidded plastic containers containing artificial diet, remaining there until the pupa phase.

\section{Sowing and maintenance of soybean plants}

Plastic pots $(1 \mathrm{~L})$ with 500 grams of substrate Terral Solo $\AA$ were used to sow 100 M6210 IPRO soybean plants expressing Bacillus thuringiensis (Bt) Cry1Ac protein. The plants were placed in cages with anti-aphid screen in a greenhouse. Irrigation and other cultural treatments were carried out whenever necessary. Soybean plants were used for the experiments when they reached the V3 development stage.

\section{Plant infestation, collection and chemical analysis of volatiles}

Infestations were performed simultaneously on soybean plants with 100 adult female $T$. urticae mites per plant for 24 hours and/or with two fourth-instar $A$. gemmatalis caterpillars for 36 hours prior to sampling. Headspace collection was performed according to the method proposed by Pereira et al. (2017) with adaptations. A plastic bag was used to pack the plants and an electric pump was used to inflate the air. The bag was completely heat-sealed and Teflon was used at the base to prevent air leakage. After exposure to herbivory, sterile syringes were used to collect volatiles in each treatment, which were transferred to headspace vials $(25 \mathrm{~mL})$, being identified and sealed (Figure 1).

Samples were analyzed via GC-MS system on a Trace GC Ultra gas chromatograph (Thermo Scientific, San Jose, CA) coupled to a Polaris Q mass spectrometer (ion trap) (Thermo Scientific, San Jose, CA), using solid-phase microextraction (SPME) in the headspace mode (Merkle et al., 2015). Polydimethylsiloxane/divinylbenzene (PDMS/DVB) semipolar fiber was used for vial exposure at $60^{\circ} \mathrm{C}$ for 20 minutes.

Chromatographic conditions for the collection of soybean volatiles were: injector temperature = $=200^{\circ} \mathrm{C}$; splitless injection; splitless time $=5$ minutes; ion source temperature $=200{ }^{\circ} \mathrm{C}$; interface temperature $=275{ }^{\circ} \mathrm{C}$. The heating temperature of the equipment was $40{ }^{\circ} \mathrm{C}$ for 1 minute, followed by a gradient of $5{ }^{\circ} \mathrm{C} \mathrm{min}-1$ to $110{ }^{\circ} \mathrm{C}$, isothermal maintenance for 3 minutes, a new gradient of $7{ }^{\circ} \mathrm{C} \mathrm{min}{ }^{-1}$ to $220^{\circ} \mathrm{C}$, with the temperature maintained for 1 minute and, finally, a gradient of $12{ }^{\circ} \mathrm{C} \min ^{-1}$ to $245{ }^{\circ} \mathrm{C}$, 
temperature that was also maintained for 1 minute. The detector was kept in scan mode (fullscan, 30-300) using the electron impact (EI) ionization technique with $70 \mathrm{eV}$ energy. The chromatographic column used was the HP-5 MS capillary column (5\% phenyl - 95\% methylpolysiloxane), containing the following dimensions: $30 \mathrm{~m}$ length, $0.25 \mathrm{~mm}$ internal diameter, and $0.25 \mu \mathrm{m}$ film thickness (Agilent Technologies INC, Germany).

Compounds were identified by comparisons between mass spectra present in the NIST/EPA/NIH library (2005), based on retention time values obtained from the Xcalibur 1.4 program (Thermo Electron Corporation).
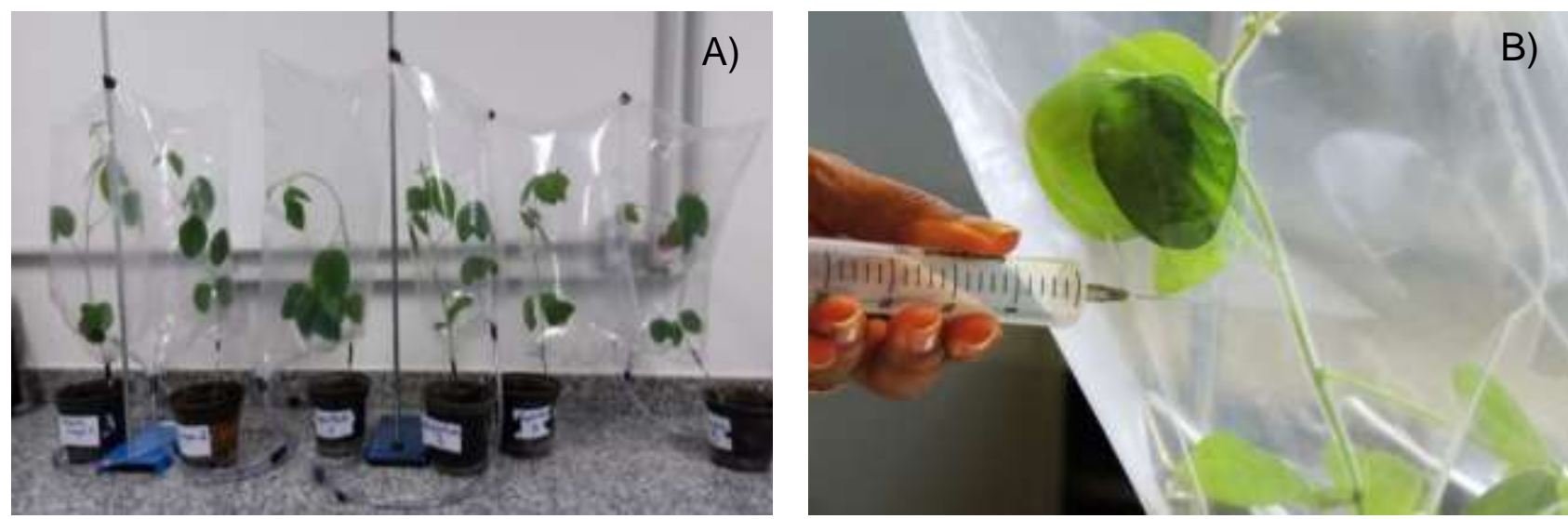

Figure 1 - A) Sealed soybean plants for the collection of volatiles. B) Collection of volatiles in a soybean plant.

\section{Statistical Analysis}

The results of the percentages of the relative areas of each sample were submitted to principal component analysis (PCA). The R program was used to perform statistical analysis and to elaborate the graphs (R Development Core Team, 2014).

\section{Results}

Eight compounds were identified and grouped into: (a) produced by clean plants infested with mites or with mites and caterpillars (camphene and 7-octen-3ol, 2,6-dimethyl); b) produced under all conditions (2octenal); c) produced only in caterpillar infestations with or without mites (lavandulol and cyclohexanol, 2methyl-5-(1-methylethyl); d) produced only by clean plants (dodecene); e) produced only by clean plants or caterpillar-free plants infested with mites (geranyl isovalerate); f) produced only by caterpillar-infested plants without mites (linalool) (Table 1).

Table 1 - Volatile organic compounds (VOC) found in soybean plants (M6210IPRO): Cleaned soybean plants (S), infested with arid-brindle, Tetranychus urticae (SA), infested with two Anticarsia gemmatalis (SL) and T. urticae + A. gemmatalis (SAL) on the same plant.

\begin{tabular}{|c|c|c|c|c|c|c|c|}
\hline $\mathrm{n}$ & VOC & Class & Chemical formule & $\mathrm{S}$ & $\mathrm{SA}$ & $\mathrm{SL}$ & SAL \\
\hline 1 & Camphene * & Monoterpene & $\mathrm{C}_{10} \mathrm{H}_{16}$ & + & + & + & + \\
\hline 2 & 2-Octenal* & Jasmonate* & $\mathrm{C}_{8} \mathrm{H}_{14} \mathrm{O}$ & + & + & + & + \\
\hline 3 & Lavandulol & Monoterpene & $\mathrm{C}_{10} \mathrm{H}_{22} \mathrm{O}$ & - & - & + & + \\
\hline 4 & Dodecene* & Jasmonate* & $\mathrm{C}_{12} \mathrm{H}_{24}$ & + & - & - & - \\
\hline 5 & Cyclohexanol,2-metil-5-(1-methylethyl) & Monoterpene & $\mathrm{C}_{10} \mathrm{H}_{20} \mathrm{O}$ & - & - & + & + \\
\hline 6 & Geranyl isovalerate & Monoterpene & $\mathrm{C}_{15} \mathrm{H}_{26} \mathrm{O}_{2}$ & + & + & - & - \\
\hline 7 & 7-Octen-3-ol,2,6dimethyl & Jasmonate* $^{*}$ & $\mathrm{C}_{10} \mathrm{H}_{20} \mathrm{O}$ & + & + & - & + \\
\hline 8 & Linalool* $^{*}$ & Monoterpene & $\mathrm{C}_{10} \mathrm{H}_{18} \mathrm{O}$ & - & - & + & - \\
\hline Toté & of compounds & & & 5 & 4 & 5 & 5 \\
\hline
\end{tabular}

$\mathrm{S}=$ uninfested soybean; $\mathrm{SA}=$ soybean infested by the arid-brindle; $\mathrm{SL}=$ soybean infested by the soybean caterpillar; $\mathrm{SAL}=$ soybean infested by the arid-brindle and the soybean caterpillar. ${ }^{*}$ Volatile organic compounds present in soybean plants previously described in the literature.

Principal component analysis of chemical parameters related to volatile composition in clean and infested soybean leaves explained $77.5 \%$ of the data variation. The samples of the three plants infested with A. gemmatalis and under multiple herbivory ( $T$. urticae and $A$. gemmatalis) were grouped in different positions, indicating that there was a difference between the volatile compounds emitted in both situations, whereas the samples of clean plants approached those with $T$. urticae infestation (Figure 2). 


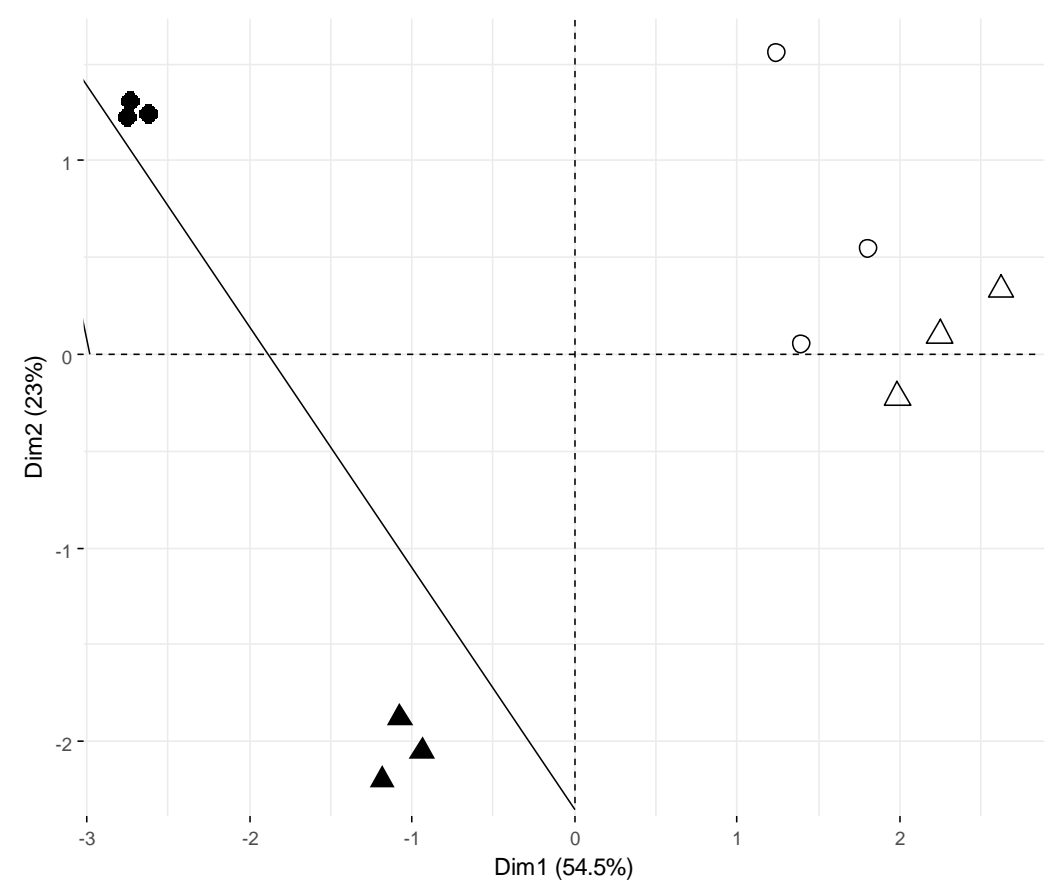

Figure 2 - Principal components analysis of volatile compounds present in soybean plants without infestation (०), soybean infected with T. urticae $(\Delta)$; soybean infested with A. gemmatalis $(\bullet)$ and soybean infected with T. urticae + A. gemmatalis $(\boldsymbol{\Lambda})$ detected via GC/MS.

Figure 3 shows the contribution of compounds to group formation, where monoterpenes lavandulol and cyclohexanol are predominant in multiple infestations (mite + caterpillar). Caterpillar-infested soybean plants activate the jasmonate route with the production of dodecene, and the isoprene route with the formation of linalool.

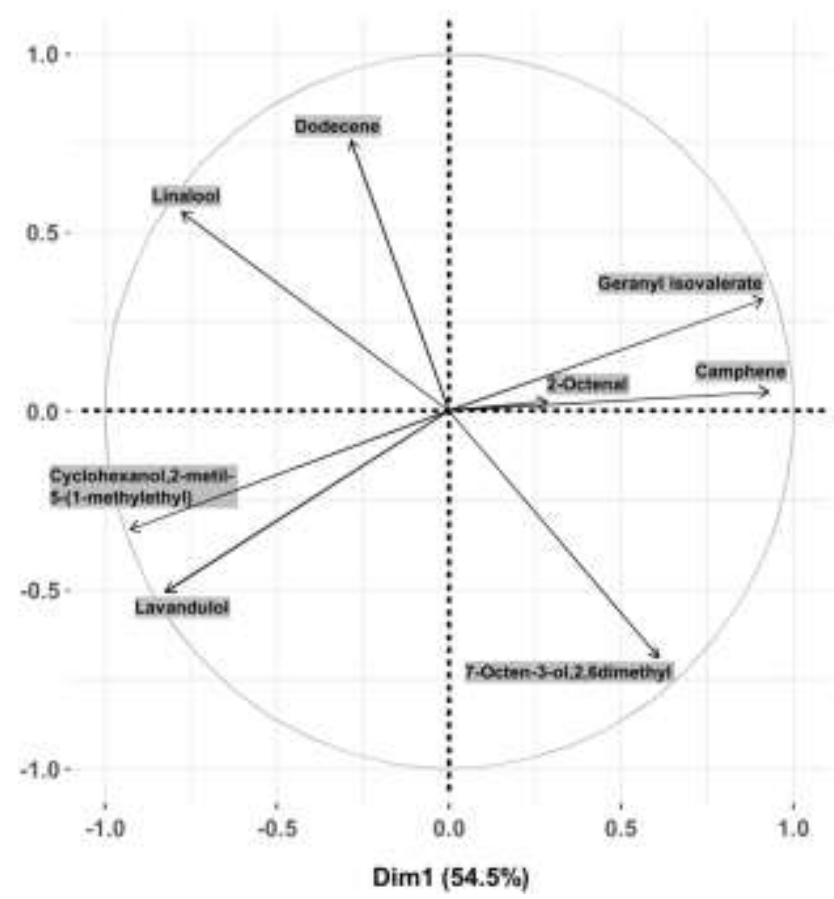

Figure 3 - Analysis of major components of volatile compounds present in soybean plants detected via GC/MS. The numbers used for compounds identification are the same of those described in Table 1. 


\section{Discussion}

Compounds camphene, 2-octenal, dodecene, and linalool, found in the present work, were also identified in soybean plants in several studies evaluating the emission of volatile compounds (Rosario et al., 1984; Liu et al., 1989; Damiani et al., 2000; Boue et al., 2003; Boer et al., 2004; Moraes et al., 2005; Zhu \& Park, 2005; Rostás \& Eggert, 2008; Michereff et al., 2011; Cai et al., 2015). Moreover, compounds 2octenal, dodecene, and 2,6-dimethyl-7-octen-3-ol, derived from jasmonate, also strongly suggest indirect induced defense, as the jasmonic acid route has been described as one of the major chemical routes of volatiles (Heil, 2014).

In the volatile analysis of clean soybean plants, compound dodecene, found exclusively in cultivar PI 227687, repelled caterpillar Trichoplusia ni (Liu et al., 1989). In turn, soybean cultivars that did not release dodecene were attractive to $T$. ni. Compound dodecene is shown to be a signaling molecule for host localization by the herbivore. Infestation conditions cause the plant to interrupt the production of this compound to benefit the herbivore so that new herbivores do not colonize the same host.

The predatory mite Phytoseiulus persimilis preferred volatiles of bean plants with low density of $S$. exigua ( 2 caterpillars per plant), repelling plants with a high density of the insect (100 caterpillars per plant). However, predators did not prefer this treatment when caterpillar feces were not removed. In that study, the authors showed that caterpillar fecal volatiles mediate the preference. Such observation is pertinent because caterpillar feces remained on the soybean leaves during the experiment, thus fecal volatiles may also have been captured.

Compound linalool, found in soybean plants infested with $A$. gemmatalis, was also found in soybean plants infested with Spodoptera frugiperda (Rostás \& Eggert, 2008). This compound may be key in indirect induced defense and assist in the foraging of natural enemies by plants infested with prey herbivores. Compound linalool was not produced by caterpillar-infested plants that were previously exposed to mite herbivory. It is suggested that some mechanism of volatile emission regulation may occur by mite herbivory.

Herbivory is shown to alter the chemical profile of volatiles emitted in soybean plants, and these volatiles possibly characterize the triggering of indirect induced defense.

\section{Conclusions}

The developed method allows to affirm that the compounds found are released by soybean plants after herbivore manipulation, without possible interference of mechanical damage caused in the maceration process. Future work should be developed testing the preference for natural enemies to clarify field foraging.

\section{References}

Aartsma Y, Bianchi FJJA, Werf van der W, Poelman EH, Dicke M (2017) Herbivore-induced plant volatiles and tritrophic interactions across spatial scales. New Phytologist 216:1054-1063. Doi: 10.1111/nph.14475

Boer JG, Posthumus MA (2004) Identification of volatiles that are used in discrimination between plants infested with prey or nonprey herbivores by a predatory mite. Journal of Chemical Ecology 30(11):2215-2230. Doi: 10.1023/B:JOEC.0000048784.79031.5e

Boue SM, Shih BY, Carter-Wientjes CH, Cleveland TE (2003) Identification of volatile compounds in soybean at various developmental stages using solid phase microextraction. Journal of Agricultural and Food Chemistry 51(17):4873-4876. Doi: 10.1021/jf030051q

Cai L, Koziel JA, O’Neal ME (2015) Studying plantinsect interactions with solid phase microextraction: Screening for airborne volatile emissions response of soybeans to the soybean aphid, Aphis glycines Matsumura (Hemiptera: Aphididae). Chromatography 2(2):265-276. Doi: 10.3390/chromatography2020265

Coley PD, Barone JA (1996) Herbivory and plant defenses in tropical forests. Annual Review of Ecology and Systematics 27(1):305-335. Doi: 10.1146/annurev.ecolsys.27.1.305

Damiani P, Cossignani L, Castellini M, Bin F (2000) Clean recovery and HRGC-MS/HRGC FTIR identification of volatiles from soybean (Glycine max). Italian Journal of Food Science 12(2):175-182.

Dicke M, Van Loon JJA, Soler R (2009) Chemical complexity of volatiles from plants induced by multiple attack. Nature Chemical Biology 5(5):317-324.Doi: 10.1038/nchembio.169

Giron D, Dubreuil G, Bennett A, Dubreuil G, Bennett A, Dedeine $F$, Dicke M, Dyer LA., Erb M, Harris MO, Huguet E, Kaloshian I, Kawakita A, Lopez-Vaamonde C, Palmer TM, Petanidou T, Poulsen M, Salle A, Simon J, Terblanche JS, Thiery D, Whiteman NK, Woods HA, Pincebourde S (2018) Promises and challenges in insect-plant interactions. Entomologia Experimentalis et Applicata 166(5):319-343 Doi: 10.1111/eea.12679

Gomes LC, Lima ACA, Barbosa PGA, Costa RS, Nascimento RF (2017) Allergenic Fragrances Analysis in Brazilian Perfumes by Headspace Solid Phase Microextraction and Gas Chromatography-Mass Detector (HS-SPME-GC-MS). Journal of the Brazilian Chemical Society 28(11):2136-2145. Doi:10.21577/0103-5053.20170062

Guedes JVC, Navia D, Lofego AC, Dequech STB (2007) Ácaros associados à cultura da soja no Rio Grande do Sul. Neotropical Entomology 36(2):288$-293$. 
Heil M (2014) Herbivore-induced plant volatiles: targets, perception and unanswered questions. New Phytologist 204(2):297-306. Doi: 10.1111/nph.12977

Leitner M, Boland W, Mithöfer (2005) A direct and indirect defences induced by piercing-sucking and chewing herbivores in Medicago truncatula. New Phytologist 167(2):597-606. Doi: 10.1111/j.14698137.2005.01426.x

Liu SH, Norris DM, Lyne P (1989) Volatiles from the foliage of soybean, Glycine max, and Lima Bean, Phaseolus lunatus: Their behavioral effects on the insects Trichoplusia ni and Epilachna varivestis. Journal of Agricultural and Food Chemistry (2):496-501. Doi: 10.1021/jf00086a050

Merkle S, Kleeberg KK, Fritsche J (2015) Recent developments and applications of solid phase microextraction (SPME) in food and environmental analysis - A review. Chromatography 2(3):293-381. Doi: 10.3390/chromatography2030293

Michereff MFF, Laumann RA, Borges M, MichereffFilho M, Diniz IR, Farias Neto ALMCB, Moraes I (2011) Volatiles mediating a plant herbivore natural enemy interaction in resistant and susceptible soybean cultivars. Journal of Chemical Ecology 37(3):273-385. Doi: 10.1007/s10886-011-9917-4

Moraes MCB, Laumann R, Sujii ER, Pires C, Borges M (2005) Induced volatiles in soybean and pigeon pea plants artificially infested with the neotropical brown stink bug, Euschistus heros, and their effect on the egg parasitoid, Telenomus podisi. Entomologia Experimentalis et Applicata 115(1):227-237doi: 10.1111/j.1570-7458.2005.00290.x

Moscardi F, Bueno AF, Sosa-Gómez DR, Roggia S, Hoffmann-Campo CB, Pomari AF, Corso IC, Yano SAC (2012) Artrópodes que atacam as folhas da soja. Soja: manejo integrado de insetos e outros artrópodespraga 1th edn. Embrapa Soja 91(1):213-334.Doi: 10.1111/tpj.13545

Pereira L, Pujol M, Garcia-Mas J, Phillips MA (2017) Non-invasive quantification of ethylene in attached fruit headspace at 1 p.p.b. by gas chromatography-mass spectrometry. The Plant Journal 91:172-183.

Ponzio C, Cascone P, Cusumano A, Weldegergis BT, Fatouros NE, Guerrieri E, Dicke M, Gols R (2016) Volatile-mediated foraging 363och363ior of three parasitoid species under conditions of dual insect herbivore attack. Animal Behaviour 111:197-206. doi:10.1016/j.anbehav.2015.10.024

$\mathrm{R}$ Development Core Team. A Language and Environment for Statistical Computing (2014)R Foundation for Statistical Computing, Vienna. Available at:http://www.r-project.
Razmjou J, Tavakkoli H, N M (2009) life history traits of tetranychus urticae 363och on three legumes (Acari: Tetranychidae). Mun. Ent. Zool. 4 (1): 204-211.

Rezende JM, Lofego AC, Nuvoloni FM, Navia D (2014) Mites from Cerrado fragments and adjacent soybean crops: does the native vegetation help or harm the plantation? Experimental and Applied Acarology 64(4):501-518.Doi: 10.1007/s10493-014-9844-5

Roggia S, Guedes JVC, Kuss RCR, Arnemannll JA; Návia DI (2008) Spider mites associated to soybean in Rio Grande do Sul, Brazil. Pesquisa Agropecuária Brasileira 43(3):295-301.Doi: 10.1590/S0100204X2008000300002

Rosario R, Lumen BO, Habu T, Flath RA, Mon TR, Teranishi $R$ (1984) Comparison of headspace volatiles from winged beans and soybeans. Journal of Agricultural and Food Chemistry 32(5):1011-1015. Doi: 10.1021/jf00125a015

Rostás M, Eggert K (2008) Ontogenetic and spatiotemporal patterns of induced volatiles in Glycine max in the light of the optimal defence hypothesis. Chemoecology 18 (1):29-38. Doi: 10.1007/s00049007-0390-z

Poecke RM, Dicke M (2004) Indirect defence of plants against herbivores: using Arabidopsis thaliana as a model plant. Journal of Plant Biology 6(4):387-401. Doi: 10.1055/s-2004-820887

Vilela M, Mendes SM, Valicente FH, Carvalho SSS, Santos AE, Santos CA, Barbosa TAN, Carvalho EAR, Costa VHD (2014) Metodologia para criação e manutenção de Helicoverpa 363rmígera em laboratório. EMBRAPA: Brasília, 7p. (Circular técnica, ISSN 16791150).

Yoneya K, Takabayashi J (2014) Plant communication mediated by airborne signals: ecological and plant physiological perspectives. Plant Biotechnology Journal 31(5):409-416. Doi: 10.5511/plantbiotechnology.14.0827a

Zhang PJ, Zhenga S, van Loon JJA, Boland W, David A, Mumm R, Dicke M (2009) Whiteflies interfere with indirect plant defense against spider mites in Lima bean. Proceedings of the National Academy of Sciences 106(50):21202-21207 Doi: 10.1073/pnas.0907890106

Zhu JW, Park KC (2005) Methyl salicylate, a soybean aphid-induced plant volatile attractive to the predator Coccinella septempunctata. Journal of Chemical Ecology 31(8):1733-1746. Doi: 10.1007/s10886-0055923-8 